УДК 579.222:615.322:615.451.2

РОЗРОБКА СПОСОБУ ОТРИМАННЯ СТАБІЛЬНИХ СУБСТАНЦІЙ ДЛЯ ФУНКЦІОНАЛЬНИХ ХАРЧОВИХ ПРОДУКТІВ НА ОСНОВІ ПОРОШКУ КОРЕНЕВИХ БУЛЬБ ЯКОНА (SMALLANTHUS SONCHIFOLIUS POEPP. \& ENDL.) ТА ДОСЛІДЖЕННЯ ЇХНЬОЇ ЦУКРОЗНИЖУВАЛЬНОЇ АКТИВНОСТІ У ЩУРІВ

\author{
О. Горбулінська', М. Хохла', Г. Гачкова', А. Зинь², \\ Р. Вільданова ${ }^{3}$, О. Шульга ${ }^{3}$ Л. Міщенко ${ }^{4}$, Н. Сибірна \\ ${ }^{1}$ Львівський національний університет імені Івана Франка \\ вул. Грушевського, 4, Львів 79005, Україна \\ e-mail: Aleksaa82@gmail.com \\ ${ }^{2}$ Науково-дослідний експертно-криміналістичний центр при ГУМВС України у Львівській \\ області, вул. Збиральна, 24, Львів 79040, Україна \\ ${ }^{3}$ /нститут фрізико-органічної хімії і вуглехімії імені Л. М. Литвиненка \\ вул. Наукова, За, Львів 70060, Україна \\ ${ }^{4}$ Київський національний університет імені Тараса Шевченка \\ вул.Володимирська, 64/13, Київ 01601, Україна
}

Запропоновано способи отримання стабільної субстанції для функціонального харчового продукту з цукрознижувальною і антиоксидантною дією на основі порошку кореневих бульб якона. Метою дослідження було розробити спосіб стабілізації субстанції, яка може бути основою фрункціонального харчового продукту з використанням кореневих бульб якона і дослідити зміни гіпоглікемічного ефекту водних суспензій кореневих бульб якона після стабілізації біокомплексом PS на моделі експериментального цукрового діабету. Стабілізовану основу функціонального харчового продукту отримували кількома способами: додаванням до контрольної суспензії поверхнево-активного біокомплексу PS у концентраціях 0,00001 г/мл, 0,00002 г/мл, 0,00003 г/мл в 1 мл суспензій і з використанням порошку кореневих бульб якона, який попередньо змішували з біокомплексом PS у концентрації 0,00001 г/мл води. У результаті проведеного дослідження було з'ясовано, що обидва способи отримання стабільних субстанцій для функціональних харчових продуктів забезпечують одержання агрегативно стійких суспензій. Застосування біокомплексу PS не впливає на стабільність досліджуваних субстанцій, але попереднє додавання до порошку біокомплексу PS є зручнішим для технології виготовлення капсульованих форм біопрепаратів. Додавання біокомплексу PS до суспензії кореневих бульб якона дає змогу підвищити точність дозування субстанції та збільшити біодоступність біологічно активних речовин. Це вказує більш виражена гіпоглікемічна дія стабілізованої форми суспензії.

ISSN 1996-4536 (print) • ISSN 2311-0783 (on-line) • Біологічні Студії / Studia Biologica • 2016 • Том 10/№2 • С. 33-44 
Ключові слова: якон (Smallanthus Sonchifolius Poepp. \& Endl.), біогенні поверхнево-активні речовини, Pseudomonas sp. PS-17, гіпоглікемічний ефект, експериментальний цукровий діабет.

\section{ВСТУП}

Одним із пріоритетних завдань сучасності $є$ впровадження в клінічну практику нових підходів лікування цукрового діабету. На особливу увагу заслуговує використання функціональних харчових продуктів, збагачених не лише вітамінами та мінеральними речовинами, але й біологічно активними речовинами рослинного походження. Головною перевагою компонентів рослинної сировини над лікарськими засобами синтетичного походження $є$ те, що вони швидше й активніше включаються в біохімічні процеси у людському організмі, нормалізуючи функціональний стан окремих органів і систем, та позитивно впливають на обмін речовин [4].

Якон (Smallanthus sonchifolius Poepp. \& Endl., синонім Рolymnia sonchifolia Poepp. \& Endl.) - це рідкісна для Європи культура, яка є джерелом цінних біологічно активних речовин. Відомо, що якон має цукрознижувальні, протимікробні, протигрибкові й антиоксидантні властивості. Рослинна сировина, отримана з кореневих бульб якона, збагачена поліфенолами (хлорогеновою та феруловою кислотами), незамінною амінокислотою - триптофраном і фруктоолігосахаридами [2, 3, 8]. Синергічна дія біологічно активних речовин кореневих бульб якона дає змогу використовувати цю рослину як перспективне джерело для створення функціональних харчових продуктів, які можна буде рекомендувати хворим на цукровий діабет.

Попередньо проведені скринінгове дослідження гіпоглікемічної дії водних екстрактів кореневих бульб якона на моделі ЕЦД 1-го типу довели, що вони мають виражений гіпоглікемічний ефект [6]. Однак використання води як екстрагента має низку недоліків. Зокрема, її використання не забезпечує екстрагування гідрофобних речовин. Вода не має антисептичних властивостей, унаслідок чого в екстрактах можуть розвиватися мікроорганізми, завдяки воді відбувається гідролітичне розщеплення багатьох речовин, особливо за високої температури [13]. 3 огляду на вищесказане, нами була обрана інша фрорма введення досліджуваної рослинної сировини, а саме суспензія. Суспензія як лікарська фрорма дає змогу отримувати лікарські препарати пролонгованої дії (створювати депо лікарських речовин), регулювати тривалість їх дії зміною розміру часточок лікарської сировини, а також дає можливість одночасно використовувати як розчинні, так і нерозчинні лікарські речовини. Крім цього, обволікаюча дія низки лікарських речовин найбільш виражено проявляється у разі їх застосування у вигляді суспензії [1].

Виготовлення суспензій потребує дотримання вимог Державної фрармакопеї України, серед яких однорідність вмісту діючих речовин в одиниці дозованого лікарського засобу й агрегативна стійкість. Саме агрегативна стійкість впливає на точність дозування та на розподіл діючих речовин на поверхні слизової оболонки шлункого-кишкового тракту під час застосування суспензій per os $[1,11]$. Сучасне виробництво функціональних харчових продуктів потребує обґрунтованого та цілеспрямованого використання допоміжних речовин. Серед них на особливу увагу заслуговують поверхнево-активні речовини біогенного походження, які впливають на точність дозування, терапевтичну ефективність і вивільнення активної субстанції зі складу функціонального харчового продукту.

ISSN 1996-4536 (print) • ISSN 2311-0783 (on-line) • Біологічні Студії / Studia Biologica • 2016 • Том 10/№2 • С. 33-44 
У фармацевтичній промисловості для отримання агрегативно стабільних лікарських форм, у тому числі й суспензій, використовують поверхнево-активні речовини (ПАР). ПАР - це хімічні речовини, які знижують поверхневий натяг рідини, полегшуючи розтікання рідини, та знижують міжфазний натяг на межі двох рідин. ПАР $€$ амфіфільними сполуками, які містять як гідрофільну, так і гідрофобну групи, завдяки чому сприяють змочуванню тіл водою і таким чином забезпечують агрегативну стійкість суспензій [1]. ПАР поділяються на дві великі групи: природні та синтетичні (детергенти). Під час вибору стабілізаторів перевагу надають ПАР природного походження, що обумовлено їхньою високою біологічною інертністю порівняно зі синтетичними ПАР, які можуть сприяти розвитку алергічних реакцій і підвищувати токсичність препаратів [1]. ПАР біогенного походження поділяють за хімічною будовою на гліколіпіди (трегалозо-, рамно-, софорозо-, целобіозоліпіди та інші), ліпопептиди (ліпопротеїни), ліпополісахариди, жирні кислоти і їхні похідні, фосфоліпіди $[7,10]$. Перевагами ПАР біогенного походження є біодеградабельність, яка виключає забрудненість навколишнього середовища, стійкість до коливань температури, стабільність за різних значень рН середовища.

Серед перспективних мікроорганізмів-продуцентів ПАР на велику увагу заслуговують представники роду Pseudomonas, які синтезують позаклітинні рамноліпіди з високою поверхневою, емульгувальною та піноутворювальною активністю. Рамноліпіди складаються з однієї або двох молекул рамнози, приєднаних до двох залишків $\beta$-гідроксидеканової кислоти [7].

Meта дослідження - розробити спосіб стабілізації субстанції, яка може бути основою функціонального харчового продукту з використанням кореневих бульб якона, та дослідити гіпоглікемічний ефект водних суспензій кореневих бульб якона після стабілізації біокомплексом PS на моделі експериментального цукрового діабету.

\section{МАТЕРІАЛИ ТА МЕТОДИ}

У дослідженні використовували кореневі бульби якона, інтродукованого у Київській області. Рослинний матеріал збирали восени та висушували при кімнатній температурі протягом 2 місяців. 31 кг свіжих кореневих бульб якона вихід повітряносухої маси становив 300 г. Сухі бульби подрібнювали за допомогою подрібнювача ріжучої та розпилювальної дії до одержання однорідної порошкоподібної маси.

Контрольну суспензію отримували змішуючи 0,075 г порошку кореневих бульб з 1 мл води.

Біокомплекс PS виділяли з надосадової культуральної рідини штаму Pseudomonas sp. PS-17 за допомогою кислотного осадження за $\mathrm{pH}$ 3,0. Отриманий осад витримували при $4{ }^{\circ} \mathrm{C}$ протягом ночі та відділяли центрифугуванням (8 000 об./хв, 20 хв), після чого сушили у вакуумі за кімнатної температури до постійної маси.

Згідно з токсикологічнім паспортом, 50 \% смертельна доза $\left(Л_{50}\right)$ біокомплексу PS за внутрішньошлункового введення для білих щурів і мишей становить більше 10 г/кг. Отже, цей біокомплекс належить до речовин 4 класу небезпеки [14]. 3 огляду на це, застосовані концентрації (0,00001-0,00003 г/мл) біокомплексу PS $€$ нетоксичними для тварин і людини.

Перший спосіб отримання стабільної субстанції для фрункціонального харчового продукту полягав у додаванні до контрольної суспензії поверхнево-активного біокомплексу PS у таких концентраціях: 0,00001 г/мл, 0,00002 г/мл, 0,00003 г/мл.

ISSN 1996-4536 (print) • ISSN 2311-0783 (on-line) • Біологічні Студії / Studia Biologica • 2016 • Том 10/№2 • С. 33-44 
Стабільну субстанцію для функціонального харчового продукту отримували також іншим способом з використанням порошку кореневих бульб якона, який попередньо змішували з біокомплексом PS. Для цього однорідну порошкоподібну масу кореневих бульб поміщали у ємність рівномірним тонким шаром (товщиною не більше 2 мм), після чого по всій поверхні порошку розпилювали біокомплекс PS із розрахунку 0,00001 г/мл води на 0,075 г порошку якона. Після висихання порошок кореневих бульб змішували з 1 мл води.

Агрегативну стійкість суспензії оцінювали за рівномірним розподілом частинок у дисперсійному середовищі та за швидкістю утворення осаду на 15-ту хвилину експерименту.

Експериментальні дослідження проводили на білих безпородних щурах самцях масою тіла 130-180 г з дотриманням загальних етичних принципів проведення експериментів на тваринах згідно із „Загальними принципами роботи на тваринах”, затвердженими I Національним конгресом з біоетики (Київ, Україна, 2001) і погодженими з положеннями "Європейської конвенції із захисту хребетних тварин, які використовуються в експериментальних та інших наукових цілях" (Страсбург, Франція, 1985) та Законом України "Про захист тварин від жорстокого поводження" від 26.02.2006 р. Протокол засідання Біоетичного комітету біологічного факультету ЛНУ імені Івана Франка від № 17 від 23 червня 2016 р.

Експериментальний цукровий діабет 1-го типу індукували внутрішньоочеревинним введенням стрептозотоцину (“Sigma”, США) з розрахунку 5,5 мг на 100 г маси тіла. Концентрацію глюкози у крові вимірювали глюкозооксидазним методом. Для досліджень використовували тварин із рівнем глюкози 14 ммоль/л і більше (після 18-годинного голодування). Через два тижні після індукції цукрового діабету тваринам per os вводили суспензії якона.

Контрольну суспензію і стабілізовану її фрорму протягом 14 днів вводили тваринам per os у дозі 500 мг/кг маси тіла.

В експериментальних дослідженнях використовували такі групи тварин: 1) контрольні тварини (К); 2) контрольні тварини, яким вводили контрольну суспензію кореневих бульб і її стабілізовану форму (К+C та $\left.\mathrm{K}+\mathrm{C}^{\mathrm{Ps}}\right)$; 3) тварини з експериментальним цукровим діабетом (ЕЦД); 4) тварини з ЕЦД, яким вводили контрольну суспензію кореневих бульб і її стабілізовану форму (ЕЦД+С та ЕЦД+С ${ }^{\mathrm{Ps}}$ ).

Глюкозотолерантний тест проводили вранці після 18-годинного голодування тварин. До та після вуглеводного навантаження проводили забір крові з хвостової вени щурів і визначали рівень глюкози. На основі одержаних результатів будували графрік - глікемічну криву, що доводить, як швидко організм щурів засвоює глюкозу та як змінюється рівень цукру в крові у разі введення суспензій якона (натще 0 точка, через 10, 20, 30, 40, 50, 60 хв після споживання глюкози). Як критерій сумарної відповіді на стандартний глюкозотолерантний тест розраховували інтегральний показник площі під глікемічними кривими (area under a curve - AUCglu), що відображає загальне підвищення концентрації глюкози після споживання глюкози. AUCglu розраховували за допомогою правила трапецій [15].

Вміст глікозильованого гемоглобіну (HbA1c) визначали колориметричним методом і виражали у відсотках від загального вмісту гемоглобіну [12].

Статистичну обробку результатів проводили, використовуючи $t$-критерій Стьюдента з пакету аналізу даних комп'ютерної програми Microsoft Excel. Дані представлено у вигляді $\mathrm{M} \pm \mathrm{m}(\mathrm{n})$. Відмінність вважали вірогідною при загальноприйнятій у медико-біологічних дослідженнях ймовірності похибки $\mathrm{P}<0,05$.

ISSN 1996-4536 (print) • ISSN 2311-0783 (on-line) • Біологічні Студії / Studia Biologica • 2016 • Том 10/№2 • С. 33-44 


\section{РЕЗУЛЬТАТИ ДОСЛІДЖЕНЬ І ЇХНЄ ОБГОВОРЕННЯ}

У процесі змішування порошку кореневих бульб якона з водою (контрольна суспензія) отримали грубу суспензію з розміром часток $5 \times 10^{-3}-1 \times 10^{-2}$ см. Після 15-хвилинного вистоювання контрольна суспензія розшаровується і частинки порошку кореневих бульб осідають (рис. 1). Така суспензія $є$ неструктурованою та нестійкою в часі. Відносно великі частинки порошку якона не здатні протистояти дії сили тяжіння і, відповідно, суспензія швидко розшаровується з утворенням осаду, тобто система є седиментаційно нестійкою. У таких агрегативно нестійких суспензіях осідання відбувається значно швидше внаслідок утворення великих агрегатів частинок. Сили зчеплення між ними є співрозмірні зі силою їхнього тяжіння [1].

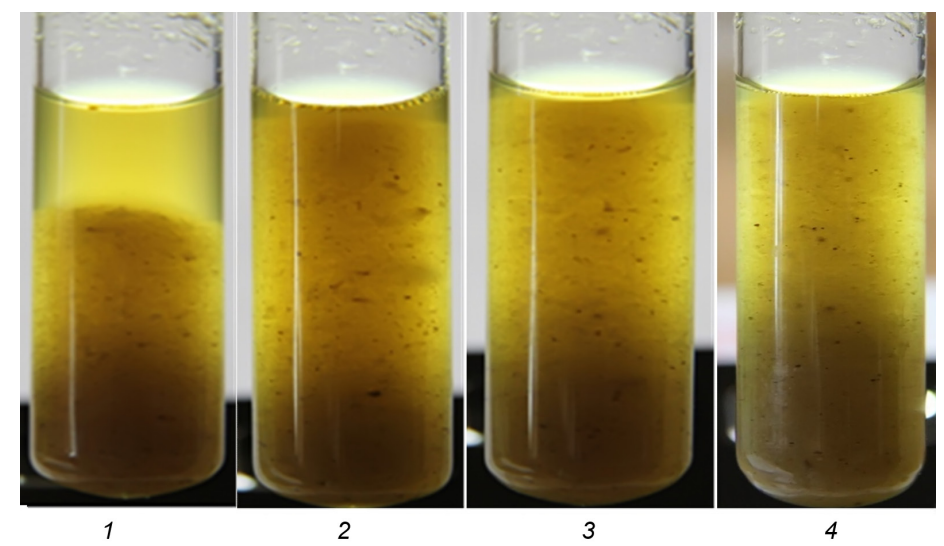

Рис. 1. Водні суспензії порошку якона через 15 хв після приготування: 1 - контрольна суспензія; 2 водна суспензія порошку якона, до якої додано біокомплекс PS у концентрації 0,00001 г/мл; 3 - водна суспензія порошку якона, до якої додано біокомплекс PS у концентрації 0,00002 г/мл; 4 - водна суспензія порошку якона, до якої додано біокомплекс PS у концентрації 0,00003 г/мл

Fig. 1. Water suspensions of yacons powder $15 \mathrm{~min}$ after preparation: 1 - control suspension; 2 - yacons powder water suspension to which biocomplex PS in the concentration of $0.00001 \mathrm{~g} / \mathrm{ml}$ was added; 3 - yacons' powder water suspension to which biocomplex PS in the concentration of $0.00002 \mathrm{~g} / \mathrm{ml}$ was added; 4 -yacons' powder water suspension to which biocomplex PS in the concentration of $0.00003 \mathrm{~g} / \mathrm{ml}$ was added

3 огляду на вищесказане, як стабілізатор функціональних харчових продуктів нами було обрано біокомплекс PS, основними складовими якого є рамноліпіди. Застосування біокомплексу PS у концентрації 0,00003 г/1 мл сприяло підвищенню агрегативної стійкості суспензії. Зокрема, вона залишалася седиментаційно стійкою протягом 15 хвилин. У разі додавання біокомплексу PS у нижчих концентраціях (0,00002 г/1 мл і 0,00001 г/1 мл) отриманий результат був практично аналогічним попередньому (рис. 1). Додавання до контрольної суспензії біокомплексу PS у всіх досліджуваних концентраціях зумовлює підвищення змочуваності частинок порошку якона, що перешкоджає їхній адсорбції на стінках скляних пробірок (рис. 2). Найвища концентрація біокомплексу PS зумовлює найкращу змочуваність частинок порошку, але і найнижчі концентрації $€$ достатніми для отримання стабільних суспензій. Продемонстрований ефект біокомплексу PS може сприяти полегшенню введення препаратів у шлунково-кишковий тракт піддослідним тваринам без втрати активної субстанції на стінках катетерів.

ISSN 1996-4536 (print) • ISSN 2311-0783 (on-line) • Біологічні Студії / Studia Biologica • 2016 • Том 10/№2 • С. 33-44 

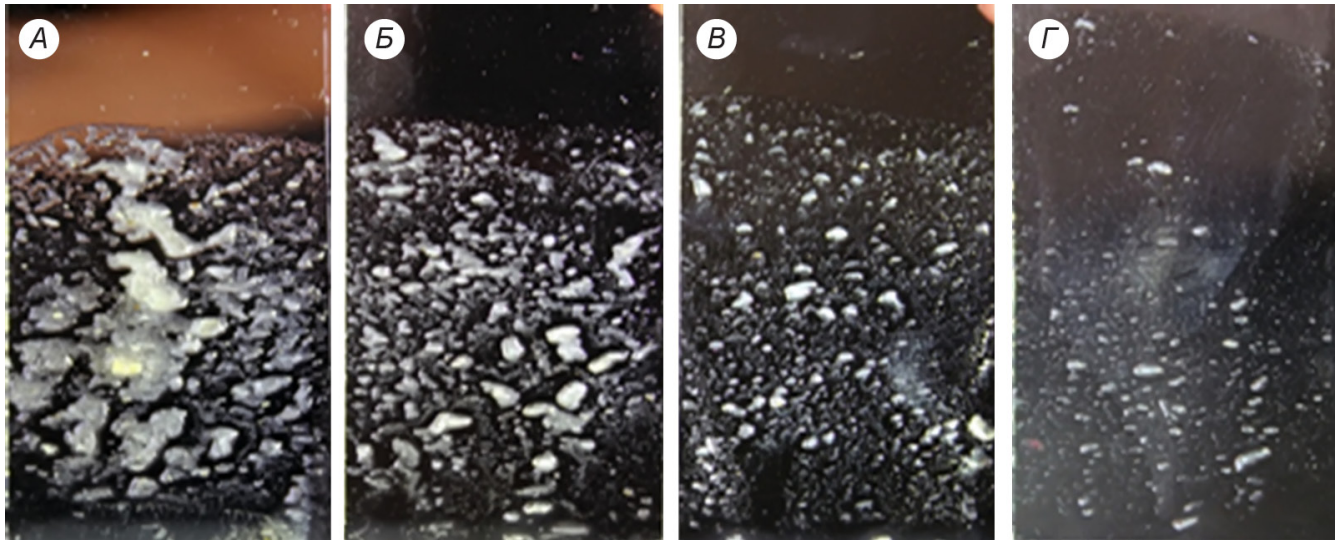

Рис. 2. Налипання суспензій порошку якона на стінках пробірок: $A$ - контрольна суспензія; $Б$ - водна суспензія порошку якона, до якої додано біокомплекс PS у концентрації 0,00001 г/мл; $B$ - водна суспензія порошку якона, до якої додано біокомплекс PS у концентрації 0,00002 г/мл; Г- водна суспензія порошку якона, до якої додано біокомплекс PS у концентрації 0,00003 г/мл

Fig. 2. Adhesion of yacons powder suspensions to the tubes walls: $A$ - control suspension; $\overline{-}-$ yacons powder water suspension to which biocomplex PS in the concentration of $0.00001 \mathrm{~g} / \mathrm{ml}$ was added; $B$ - yacons' powder water suspension to which biocomplex PS in the concentration of $0.00002 \mathrm{~g} / \mathrm{ml}$ was added; $\Gamma$ - yacons' powder water suspension to which biocomplex PS in the concentration of $0.00003 \mathrm{~g} / \mathrm{ml}$ was added

Оскільки на першому етапі дослідження встановлено, що для підвищення стійкості суспензії достатньо використовувати найменшу досліджувану концентрацію біогенних ПАР, нами було запропоновано до сухого порошку кореневих бульб якона додавати біокомплекс PS саме у цій концентрації. Встановлено, що порошок після додавання стабілізатора та висихання не змінює свого вигляду (рис. 3).
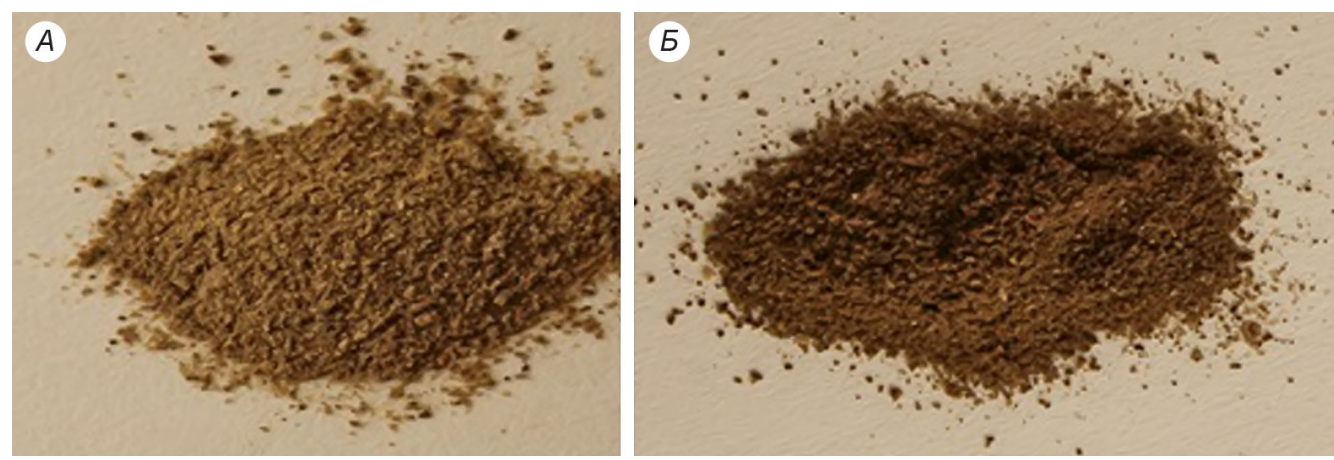

Pис. 3. Порошок якона: $A$ - без обробки біокомплексом PS; 5 - після попередньої обробки біокомплексом PS

Fig. 3. Yacons' powder: $A$ - without processing by by the PS biocomplex; $\overline{-}$ - after pretreatment with PS biocomplex

Суспензія виготовлена з попередньо обробленого порошку кореневих бульб якона є агрегативно та седиментаційно стійкою протягом 15 хв (рис. 4).

ISSN 1996-4536 (print) • ISSN 2311-0783 (on-line) • Біологічні Студії / Studia Biologica • 2016 • Том 10/№2 • С. 33-44 
Рис. 4. Водні суспензії кореневих бульб якона: 1 контрольна суспензія; 2 - порошок якона, який був попередньо змішаний з біокомплекcom PS, після чого була приготована водна суспензія

Fig. 4. Water suspensions of yacons' root tubers: $1-$ control suspension; 2 - yacons' powder which was premixed with PS biocomplex and then water suspension has been prepared

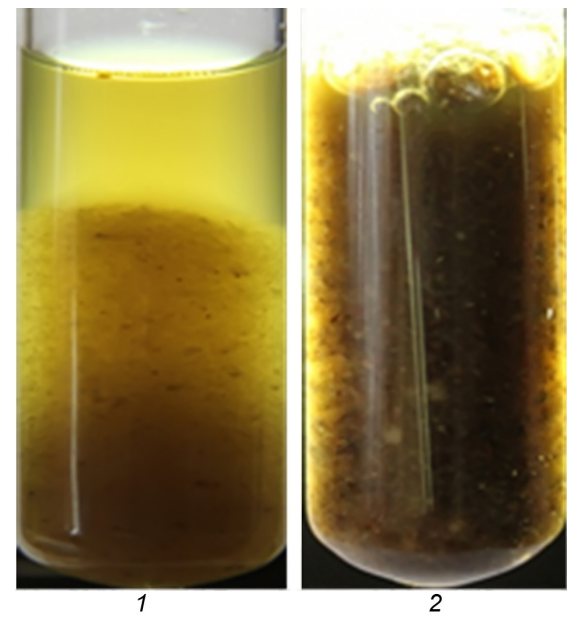

Отже, обидва запропоновані способи отримання стабілізованої субстанції фрункціонального харчового продукту (з додаванням біокомплексу PS до суспензій порошку кореневих бульб якона та з додаванням до порошку якона біокомплексу PS) дають можливість отримати водні суспензії, які $є$ седиментаційно стабільними упродовж 15 хв (рис. 1 та 4).

Підвищення стабільності суспензії при використанні біокомплексу PS обумовлено фрізико-хімічними властивостями рамноліпідів, що містяться у його складі. Зокрема, їхньою здатністю до адсорбції на поверхні твердих частинок із орієнтацією певним чином завдяки дипольній структурі їхньої молекули; до зниження міжфазного натягу на межі розподілу фаз і, відповідно, зниження енергії Гібса; до утворення захисної плівки (моно- і полімолекулярних шарів), сольватних шарів, подвійних електричних шарів; до підвищення в'язкості розчину [5]. Рамноліпіди здатні змінювати проникність клітинних мембран, підвищувати активність ферментів, регулювати ріст і метаболізм клітин. Зміну проникності біологічних мембран для різних речовин пов'язують із взаємодією поверхнево-активних речовин біогенного походження з мембранними білками та ліпідами [7].

Спосіб застосування біокомплексу PS особливо не впливає на стабільність отриманих суспензій, але попереднє додавання до порошку біокомплексу PS є зручнішим для розроблення технології отримання капсульованих форм біопрепаратів.

Контрольна суспензія кореневих бульб якона у разі ії введення тваринам з ЕЦД виявляє виражений гіпоглікемічний ефект, на що вказує зниження базального рівня глюкози на 39,28 \%, що, відповідно, супроводжувалося зниженням вмісту і глікозильованого гемоглобіну на 5,58 \% (див. таблицю). Встановлений цукрознижувальний ефект може бути зумовлений пригніченням всмоктування харчових вуглеводів з шлунково-кишкового тракту під дією біологічно активних речовин у складі кореневих бульб. Підтвердженням цього припущення є зміна характеру засвоєння глюкози у разі введенні тваринам з ЕЦД контрольної суспензії. Зокрема, після глюкозного навантаження встановлено різке підвищення рівня глюкози вже на 10-ту і 20-ту хвилину з подальшим поступовим ії̈ зниженням вже на 30-ту хвилину та з поверненням концентрації до вихідного рівня вже на 40-ву хвилину експерименту (рис. 5, A). Встановлені зміни глікемічної кривої зумовлюють зниження AUCglu на 43,21\% (див. таблицю).

ISSN 1996-4536 (print) • ISSN 2311-0783 (on-line) • Біологічні Студії / Studia Biologica • 2016 • Том 10/№2 • С. 33-44 
Динаміка змін концентрації глюкози, глікозильованого гемоглобіну, показника площі під глікемічною кривою на тлі введення суспензій кореневих бульб якона контрольним тваринам і тваринам 3 ЕЦД ( $\mathrm{M} \pm \mathrm{m}, \mathrm{n}=8-10)$

Dynamics of glucose and glycated hemoglobin concentration, index of area under the curve against the background of yacons root tubers suspensions administration to control animals and animals with experimental diabetes mellitus $(M \pm m, n=8-10)$

\begin{tabular}{|c|c|c|c|}
\hline $\begin{array}{c}\text { Умови } \\
\text { експерименту }\end{array}$ & $\begin{array}{c}\text { Концентрація } \\
\text { глюкози, ммоль/л }\end{array}$ & Вміст НbA1c, \% & AUCglu, ммоль/л×хв \\
\hline K & $4,84 \pm 0,26$ & $6,03 \pm 0,06$ & $150,63 \pm 10,58$ \\
\hline $\mathrm{K}+\mathrm{C}$ & $7,63 \pm 0,33^{*}$ & $6,38 \pm 0,14$ & $123,78 \pm 6,36^{*}$ \\
\hline $\mathrm{K}+\mathrm{C}^{\mathrm{Ps}}$ & $6,13 \pm 0,30^{*}$ & $7,16 \pm 1,12^{*}$ & $120,88 \pm 6,53^{*}$ \\
\hline ЕЦД & $22,48 \pm 2,83^{*}$ & $10,03 \pm 0,44^{*}$ & $309,54 \pm 37,46^{*}$ \\
\hline ЕЦД+С & $8,83 \pm 1,12^{\text {*\# }}$ & $9,47 \pm 1,01^{* \#}$ & $175,80 \pm 8,95^{\star \#}$ \\
\hline ЕЦД+C ${ }^{P s}$ & $8,67 \pm 0,75^{\star \#}$ & $8,53 \pm 1,03^{* \#}$ & $163,95 \pm 16,99^{\star \#}$ \\
\hline
\end{tabular}

Після введення тваринам з ЕЦД стабілізованої форми суспензії встановлено більш виражену її гіпоглікемічну дію порівняно з введенням контрольної суспензії. Базальний рівень глюкози знижувався на 40,10 \%, з подальшим зниженням концентрації HbA1c на 14,95 \% (див. таблицю). Стабілізована форма суспензії у разі її введення тваринам з діабетом зумовлює сповільнення всмоктування глюкози у кров, про що свідчить незначне зростання концентрації глюкози на 10-ту хвилину, а на 20-50-ту хвилини рівень вуглеводу коливався в межах базального значення (рис. 5, A). Варто відмітити, що на 60-ту хвилину експерименту рівень цукру в крові був нижчим ніж на початку глюкозного навантаження, що супроводжується зниженням AUCglu на 47,03 \% (див. таблицю).

A

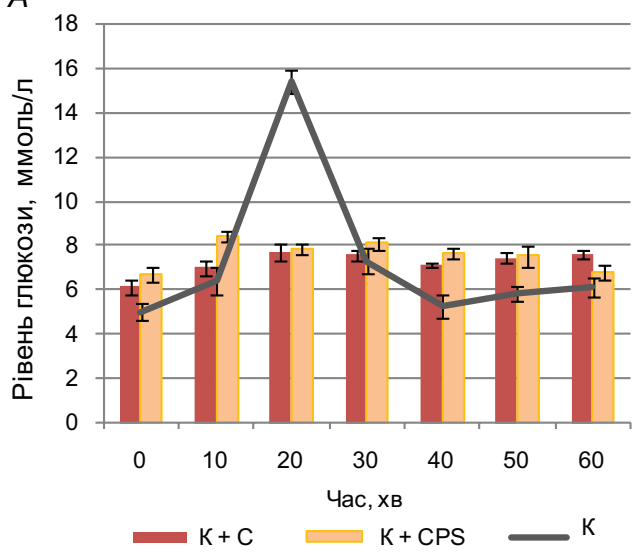

Б

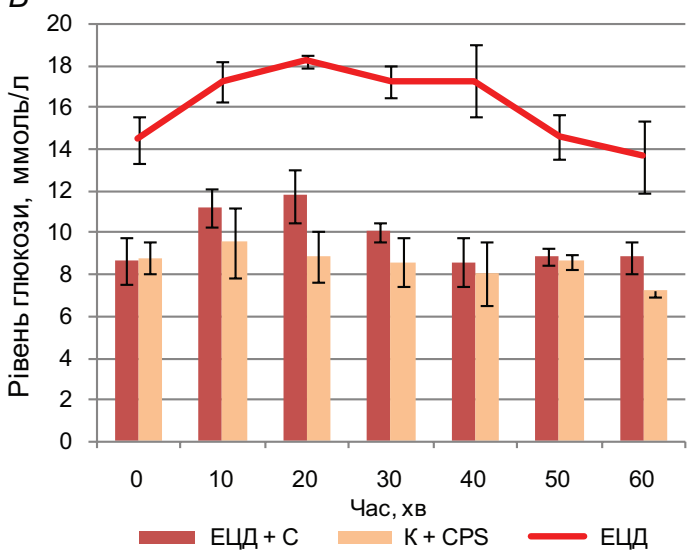

Рис. 5. Зміни концентрації глюкози після цукрового навантаження на тлі введення суспензій кореневих бульб якона: $A$ - у тварин з ЕЦД; $Б$ - у контрольних тварин

Fig. 5. Changes in glucose concentration after sugar load against the background of yacons' root tubers suspensions administration: $A$ - animals with experimental diabetes mellitus; $\bar{C}$-control animals 
У контрольних тварин встановлено підвищення рівня глюкози та вмісту HbA1c при введенні суспензій кореневих бульб якона. Можна припустити, що підвищення концентрації глюкози зумовлене наявністю у складі кореневих бульб якона глюкози (2-5 \% на суху речовину) [9]. Під час аналізу глікемічних кривих встановлено, що у здорових тварин введення і контрольної, і стабілізованої суспензій призводить до подібних змін, як і за умов ЕЦД (рис. 5, Б). Зокрема, після цукрового навантаження нами не було відмічено значних коливань концентрації глюкози, що супроводжувалося зниженням AUCglu, відповідно на 17,83 і 19,75 \%, порівняно з контролем (див. таблицю).

\section{ВИСНОВКИ}

Згідно з результатами проведених досліджень розробки способу стабілізації субстанції, яка може бути основою функціонального харчового продукту із використанням кореневих бульб якона, нами було запропоновано два способи стабілізації суспензій:

1. Перший спосіб отримання стабільної субстанції для функціонального харчового продукту полягав у додаванні до контрольної суспензії поверхнево-активного біокомплексу PS у таких концентраціях: 0,00001 г/мл, 0,00002 г/мл, 0,00003 г/мл. Встановлено, що для стабілізації субстанції достатньо використовувати поверхнево-активний біокомплекс PS у найменшій концентрації 0,00001 г/мл.

2. Другий спосіб отримання стабільної субстанції для функціонального харчового продукту полягав у використанні порошку кореневих бульб якона, який попередньо змішували з біокомплексом PS у найменшій концентрації 0,00001 г/мл.

Спосіб застосування біокомплексу PS особливо не впливає на стабільність отриманих суспензій, але попереднє додавання до порошку біокомплексу PS є зручнішим для розроблення технології отримання капсульованих форм біопрепаратів.

Розроблені способи є достатньо простими, ефективними і дають змогу отримати стабілізовані субстанції для функціональних харчових продуктів на основі порошку кореневих бульб якона у вигляді водної суспензії. Додаткове застосування біокомплексу PS дає змогу підвищити точність дозування і біодоступність діючих речовин, на що вказує більш виражена гіпоглікемічна дія стабілізованої форми суспензії.

1. Georgiyevsk V., Konev F. Technology and standardization of drugs H: Kharkiv: Rieger, 1996. 784 p. (In Ukrainian).

2. Grethel T., Delgadoa C., Thoméb R. Yacon (Smallanthus sonchifolius)-derived fructooligosaccharides improves the immune parameters in the mouse. Nutrition Research, 2012; 32: 884-892.

3. Habib N., Honoré S., Genta S. Hypolipidemic effect of Smallanthus sonchifolius (yacon) roots on diabetic rats. Biochemical Approach Instituto Superior de Investigaciones Biológicas. Argentina, 2011; 15(194): 31-9.

4. Happarov M., Wojtkiewicz N. Functional nutrition product: Theory and Practice. Methodology and Implementation of Development Programs "Healthy Nutrition", 2002: 46-50.

5. Helfman M., Kovalevych O., Yustratov V. Colloidal chemistry. $4^{\text {th }}$ ed. Publishing Hause “Lan”. St. Petersburg, 2008. 336 p. (In Russian). 
6. Horbulinska A., Khokhla M., Hachkova G. et al. Influence of yacon (Smallanthus Sonchifolius Poepp. \& Endl.) on rats' blood cells the condition of experimental diabetes mellitus. Bulletin of Lviv University. Biol. Series, 2016; 71: 31-42. (In Ukrainian).

7. Imura $T$., Yanagishita $H$. Thermodynamically stable vesicle formation from glycolipid biosurfactant sponge phase. Biointerfaces Rev, 2005; 43 (2): 115-121.

8. Lobo A., Gaievski H., Carli E. Fructooligosaccharides and iron bioavailability in anaemic rats: the effects on iron species distribution, ferroportin-1 expression, crypt bifurcation and crypt cell proliferation in the caecum. British Journal of Nutrition, 2014: 112: 1286-1295.

9. Ohyama T., Ito O., Yasuyoshi S. Composition of storage carbohydrate in tuber roots of yacon (Polymnia sonchifolia). Soil Sci. Plant. Nutr, 1990; 36: 167-171.

10. Singh A., Hamme J., Ward O. Surfactants in microbiology and biotechnology: Part 2. Application aspects. Biotechnology Advances, 2007; 25(99): 121.

11. State Pharmacopoeia of Ukraine. State Enterprise "Scientific-expert pharmacopoeia center" - $1^{\text {st }}$ Edition X: Rieger: - Extras. 1, 2004: 520. (In Ukrainian).

12. Sybirna N.O., Burda V.A. Chayka Ya.P. Methods of blood. Lviv: Publishing Center Ivan Franko LNU, 2006. 100 p. (In Ukrainian).

13. Tikhonov A., Yarnykh T. Technology of Drugs: A text book for English students of pharmaceutical higher schools and departments. PH of NUPh, Kharkiv, 2011. 517 p. (In Ukrainian).

14. Toxicological and hygienic passport of the biopreparat PS (biosurfactant PS). (Protocol examination \#01 from 27.01.2004 of the Department of Hygiene and Preventive Toxicology of the Danylo Halytsky Lviv National Medical University). Lviv, 2004. 11 p. (In Ukrainian).

15. Yeh S.T. Using trapezoidal rule for the area under a curve calculation. Proceedings of the Twenty-Seventh Annual SAS. User Group International (SUGI) Conference, 2002; 27: 229-237.

\title{
DEVELOPMENT OF OBTAINING STABLE SUBSTANCES FOR FUNCTIONAL FOOD PRODUCTS BASED ON YACONS (SMALLANTHUS SONCHIFOLIUS POEPP. \& ENDL.) POWDER ROOT TUBERS AND INVESTIGATION OF THEIR HYPOGLYCEMIC ACTIVITY IN RATS
}

\author{
A. Horbulinska', M. Khokhla', H. Hachkova', A. Zyn², \\ R. Vildanova ${ }^{3}$, O. Shulga ${ }^{3}$, L. Mishchenko ${ }^{4}$, N. Sybirna ${ }^{1}$ \\ ${ }^{1}$ Ivan Franko National University of Lviv, 4, Hrushevskyi St., Lviv 79005, Ukraine \\ e-mail:Aleksaa82@gmail.com \\ ${ }^{2}$ Research Forensic Centre at the Interior Ministry in Ukraine Lviv Region \\ 24, Zbyralna St., Lviv 79040, Ukraine \\ ${ }^{3}$ L.M. Lytvynenko Institute of Physico-Organic Chemistry and Coal Chemistry, NAS of Ukraine \\ 3a, Naukova St., Lviv 79060, Ukraine \\ ${ }^{4}$ Taras Shevchenko National University of Kyiv, 64/13, Volodymyrska St., Kyiv 01601, Ukraine
}

Methods of obtaining a stable substance for functional foods with antioxidant and hypoglycemic action based on powder root tubers of yacon' are proposed. The aim of the study was to develop a substance stabilizing method which can be the basis for functional food, using yacons root tubers and investigate the changes of hypoglycemic effect of yacons' root tubers water suspensions after stabilization with PS biocomplex under experimental model of diabetes. Stabilized basis for functional food product were received in several ways: by adding to control suspension a surface-active PS biocomplex in concentrations of $0.00001 \mathrm{~g} / \mathrm{ml}, 0.00002 \mathrm{~g} / \mathrm{ml}, 0.00003 \mathrm{~g} / \mathrm{ml}$ per $1 \mathrm{ml}$ suspension

ISSN 1996-4536 (print) •ISSN 2311-0783 (on-line) • Біологічні Студії / Studia Biologica • 2016 • Том 10/№2 • C. 33-44 
and by using yacons root tubers powder that were pre-mixed with PS biocomplex in the concentration of $0.00001 \mathrm{~g} / \mathrm{ml}$ of water. It was shown that both methods of obtaining stable substances for functional foods ensure getting the aggregation stable suspensions. Application method of PS biocomplex do not particularly affect a stability of the studied substances, but preliminary addition of PS biocomplex to the powder is convenient for development of biological preparations encapsulated forms manufacturing technology. Addition of PS biocomplex to the suspension of yacons' root tubers allows increasing the accuracy of substance dosing and increasing bioavailability of bioactive substances, that was indicated by more severe hypoglycemic effect of a suspension stabilized form.

Keywords: yacon (Smallanthus sonchifolius Poepp. \& Endl.), biogenic surfactants, Pseudomonas sp. PS-17, hypoglycemic effect, diabetes mellitus.

\title{
РАЗРАБОТКА СПОСОБА ПОЛУЧЕНИЯ СТАБИЛЬНЫХ СУБСТАНЦИЙ ДЛЯ ФУНКЦИОНАЛЬНЫХ ПИЩЕВЫХ ПРОДУКТОВ НА ОСНОВЕ ПОРОШКА КОРНЕВЫХ КЛУБНЕЙ ЯКОНА (SMALLANTHUS SONCHIFOLIUS POЕРР. \& ENDL.) И ИССЛЕДОВАНИЕ ИХ САХАРОСНИЖАЮЩЕЙ АКТИВНОСТИ У КРЫС
}

\author{
А. Горбулинская ${ }^{1}$, М. Хохла' ${ }^{1}$ Г. Гачкова ${ }^{1}$, А. Зынь², \\ Р. Вильданова ${ }^{3}$, А. Шульга ${ }^{3}$ Л. Мищенко ${ }^{4}$ Н. Сибирная ${ }^{1}$ \\ ${ }^{1}$ Львовский национальный университет имени Ивана Франко \\ ул. Грушевского, 4, Львов 79005, Украина \\ e-mail: Aleksaa82@gmail.com \\ ${ }^{2}$ Научно-исследовательский экспертно-криминалистический центр \\ при ГУМВД Украины во Львовской области \\ ул. Збиральна, 24, Львов 79040, Украина \\ ${ }^{3}$ Институт фризико-органической химии и углехимии им. Л.Н. Литвиненко НАН Украины \\ ул. Научная, За, Львов 79060, Украина \\ ${ }^{4}$ Киевский национальный университет имени Тараса Шевченко \\ ул. Владимирская, 64/13, Киев 01601, Украина
}

\begin{abstract}
В статье предложены способы получения стабильной субстанции для функционального пищевого продукта с сахароснижающим и антиоксидантным действием на основе порошка корневых клубней якона. Целью исследования было разработать способ стабилизации субстанции, которая может быть основой функционального пищевого продукта с использованием корневых клубней якона и исследование изменений гипогликемического эффректа водных суспензий корневых клубней якона после стабилизации биокомплексом PS на модели экспериментального сахарного диабета. Стабилизированную основу функционального пищевого продукта получали несколькими способами: путем добавления к контрольной суспензии поверхностно-активного биокомплекса PS в концентрациях 0,00001 г/мл, 0,00002 г/мл, 0,00003 г/мл на 1 мл суспензий и с использованием порошка корневых клубней якона, который предварительно смешивали с биокомплексом PS в концентрации
\end{abstract}

ISSN 1996-4536 (print) • ISSN 2311-0783 (on-line) • Біологічні Студії / Studia Biologica • 2016 • Том 10/№2 • С. 33-44 
0,00001 г/мл воды. В результате проведенного исследования было показано, что оба способа получения стабильных субстанций для функциональных пищевых продуктов обеспечивают получение агрегативно устойчивых суспензий. Способ применения биокомплекса PS особо не влияет на стабильность исследуемых субстанций, но предварительное добавление к порошку биокомплекса PS является удобным для разработки технологии изготовления капсулированных форм биопрепаратов. Добавление биокомплекса PS к суспензии корневых клубней якона позволяет повысить точность дозирования субстанции и увеличить биодоступность биологически активных веществ, на что указывает более выраженое гипогликемическое действие стабилизированной фрормы суспензии.

Ключевые слова: якон (Smallanthus Sonchifolius Poepp. \& Endl.), биогенные поверхностно-активные вещества, Pseudomonas sp. PS-17, гипогликемический эффект, экспериментальный сахарный диабет.

Одержано: 22.06.2016

ISSN 1996-4536 (print) • ISSN 2311-0783 (on-line) • Біологічні Студії / Studia Biologica • 2016 • Том 10/№2 • С. 33-44 